\title{
STOCK ABUNDANCE INDEX, DENSITY, COMPOSITION, AND DISTRIBUTION OF DEEP-SEA SHARK AND RAY RESOURCES IN THE EASTERN INDIAN OCEAN
}

\author{
Suprapto") and Badrudin")
}

\begin{abstract}
Deep-sea shark and ray resources in the Indian Ocean provide one of the most economically important fish mesopelagic and demersal resources. Data analyzed were part of the survey carried out in May to June 2005 in the framework of The Japan-Indonesia Deep Sea Fisheries Resources Joint Exploration Marine Research 2004. Data were obtained by using bottom trawl operataed by using the research vessel RNBaruna Jaya IV (1.219 GT) in Southern Java and Western Sumatera. The stock density of rays in the southern Java is estimated about 3.94 tonnes $\mathrm{km}^{-2}$, or about six time higher than in the western Sumatera, while the density of the sharks resources in the waters of southern Java was about 0.36 tonnes $\mathrm{km}^{-2}$, in the western Sumatera was 0.35 tonnes $\mathrm{km}^{-2}$. During the period of survey the total catch of sharks in the southern Java was almost $50 \%$ higher than in the western Sumatera. The maximum catch rate in the western Sumatera was more than three time higher compared with the maximum catch rate in southern Java, however the difference of the minimum and the mean catch rate in both areas was not statistically significant. Total of 13 species of rays belonging to the 4 familis found during the survey period were was identified and recorded. The detail 12 species found in the southern Java and only 7 species in the western Sumatera. The most abundance families in both waters are the Plesiobatidae, with species Plesiobatis sp., Plesiobatis daviesi, and Hexatrygonidae, with only one species, Hexatrygon longirostra, while a total of 21 species belonging to 11 families of mesopelagic sharks found in the waters of the Indian Ocean were was identified. The most dominant species in weight in the southern Java were Centrophorus sp. and Centrophorus moluccensis (family Centrophoridae), while in the western Sumatera was Mitsukurina owstoni.
\end{abstract}

KEYWORDS: deep-sea rays, sharks, stock abundance index, stock density, species composition, distributon, southern Java, western Sumatera, Eastern Indian Ocean

\section{INTRODUCTION}

Sharks and rays provide one of the most economically importance fisheries commodities. Almost all parts of the shark body can be utilized and have a high value. Shark fins provide the most expensive part of shark body beside meats, skin, and bone. The fins are usually exported to the international markets, while the meats are usually consumed directly either in the form of fresh or dry salted. The skin after being processed and tanned provide one of the most expensive leathers and turned into fashion accessories, such as wallets, shoes, belts, and others. Shark bones provide row material for glue while shark liver oil provide raw materials that can be further processes into cosmetics, medicines and other pharmaceutical purposes. Ray resources were not only to fulfill the demand for meat consumption but also for industrial small scale sectors. In the case of skin of sharks and rays, these material are also processed into leathers and turned into fashion accessories, such as wallets, shoes, belts, and others. Cartilaginous rays bones, also provide raw material for glue then to be utilized in wood industry and household equipments (Saleh et al., 1995). Rapid development in ray fishery drived the ray fishing technology.

Ray resources of Indonesian waters have been exploited for years by the traditional fishers, especially by using set gill net, danish seine, and bottom trawl. The fishing ground for those kinds of fishing gears are usually in coastal waters until about $100 \mathrm{~m}$ depth. The catch was almost recorded in every provincial statistics in Indonesia (Anonymous, 2005). The trend of recorded landing in each province almost increased from year to year. During 1974 to 1979 , the up trend of production occurred in North Sumatra and East Java, the two Provinces where the catch of rays are predominated the landing (Burhanudin et al., 1984). In 1993 the total rays production in Indonesia reached 35,686 tonnes (Saleh et al., 1995). In 2005 production in western Sumatera recorded 2,667 tonnes and 2,582 tonnes for south Java waters (Anonymous, 2005). This is probably due to the increasing market demand from year to year. The liong bun gill net, targetted on rays and bottom long line, have recently developed and expanded especially in the coastal waters of the Java Sea (Hufiadi et al., 2003), while other gears catching rays are usually as by-catch. 
Shark resources exploitation in Indonesia since the year 1988 (Widodo \& Widodo, 2002). Most of sharks landing are originated from tuna long line by catch, gill nets and bottom long line fisheries. Based on statistical data the production of sharks in the period 1988 to 2003 has been fluctuated from year to year ranging from 39,000 to 63,000 tonnes. In the years 2005 production of sharks in western Sumatera and south Java waters recorded 7,772 tonnes and 2,657 tonnes (Anonymous, 2005). The fishing grounds were mostly in the Indian Ocean covering the waters of the southern Java, Nusatenggara islands and western Sumatera, with the main landing place in Cilacap, Pelabuhan Ratu (southern Java), Benoa (Bali) and Tanjung Luar (Lombok Island), and Bengkulu (western Sumatera).

Shark and ray species are the member of class Elasmobranchii. Their biological characteristics are low growth rate, low fecundity, lower reaching maturity leading to longer time reproduction cycles (Castro et al., 1999; Chen et al., 1997). As the consequences recruitment will also low and higher vulnerability against high fishing intensity. These indications have been occurred for sharks in the Java Sea with the prevailed decreasing production within the period 1994 until 1999 (Dharmadi et al., 2002).

The recorded numbers of ray species in the world are between 512 to 546 species, belonging to 20 families and 64 genera that spread over the shallow waters until the deep-sea (Compagno, 1984), where the Central Pacific waters have been reported to have the highest diversity of rays in the world.

The shark distribution area is very wide and most of the populations can be found from the northern Atlantic and Pacific Ocean. In the IndoPacific area, shark can be found from Red Sea in the middle east until New Caledonia, from Japan in the north to the south of the Indian Ocean until Australia and Polynesian waters (Allen 1997). According to Demski and John (1993), the total number of recorded shark species was about 375 species, where 84 species were caught by bottom trawl in the southern waters of Indonesia and the north western Australia (Kailola \& Gloerfelt, 1984). From the observations in Pelabuhan Ratu, Cilacap, and Tanjung Luar there were about 43 species of sharks have been identified (Widodo \& Widodo, 2002) As one of the preliminary result of research collaboration between Indonesia and ACIAR/Australia, some information on shark fisheries in the Indian Ocean which were mostly based on tuna long line by-catch as well as bottom long line has also been reported (Dharmadi \& Fahmi, 2003; Dharmadi et al., 2003; Pralampita et al., 2003).

Information on the study of deep sea shark and ray resource in Indonesia is still scare, so that the availability of data on the both the fish and fisheries are considered inadequate to support the development and management of this resource. Data and information on the stock abundance index provide one of the most important indicators for sustainable development of a fishery (FAO, 1999), where catch per unit of effort can be assumed as one of the best estimates of fish abundances in the wild stock.

This paper describes the index of abundance, stock density, catch composition, distribution of sharks, and rays in the southern Java and western Sumatera, Eastern Indian Ocean within the depth range of 200 to $1,000 \mathrm{~m}$. The present information provides a complementary result that has been technically reported by the Indonesian-Japan or OFCF. It is expected that data and information in this paper provide one of the basic aspects required for the development and management of shark and ray resources in Indonesia, leading to the optimal utilization of the resources.

\section{MATERIAL AND METHODS}

Data analyzed were part of the exploratory results of research vessel RN Baruna Jaya IV $(1,219$ GT) conducted in May to June 2005 . This activity was carried out in the framework of the The Japan-Indonesia Deep Sea Fisheries Resources Joint Exploration Marine Research 2004. Fishing activities were done using bottom trawl of special designed that can be operated in the deeper waters up to more than $1,000 \mathrm{~m}$ depth.

Rays were found in the catch of 48 trawl station in Southern Java and 19 station in Western Sumatera, while sharks were occurred in the catch of 41 trawl station in Southern Java and 28 station in Western Sumatera. Towing time in each fishing station was in average of 30 minute at the vessel speed of about 3 knots. All fishing activities were done during the day time (at $08^{\circ 0}$ to $18^{\circ{ }^{\circ}}$ ). The catches were sorted, weighted and counted. Sharks and rays identifications were done and grouped into family, genus, and species following Nakabo (2002); Compagno (1984). Based on catch rate data, estimation of stock density was calculated by using swept area method following 
Shindo (1973) as described in Sparre \& Venema (1992) with the assumption of the trawl mouth opening and escapement factor are 0.66 and 0.5 , respectively. The models were based on the trawled area, speed, towing time, net opening and the catches (Sparre \& Venema, 1992) i.e:

$$
\begin{aligned}
& D=(1 / a \cdot n) \times(c / f) \\
& a \cdot n=t \cdot v \cdot h \cdot e \cdot 1,852 \cdot 0.001
\end{aligned}
$$

where:

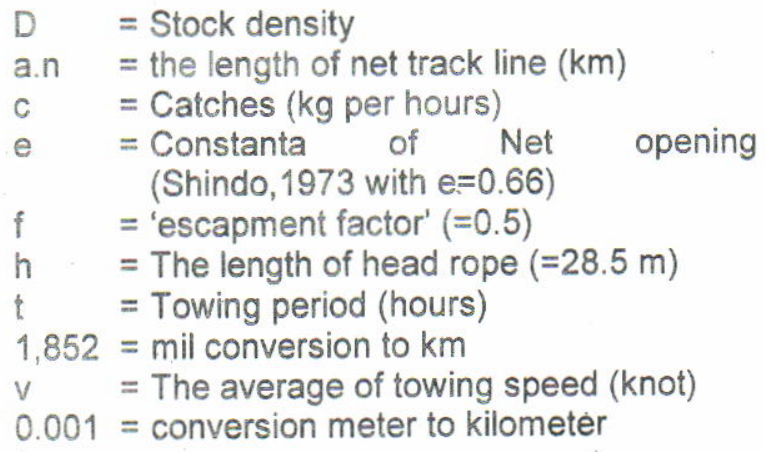

\section{RESULTS AND DISCUSSION}

\section{Stock abundance index of rays}

Based on 48 trawl fishing stations carried out in the southern Java and 19 stations in the western Sumatera, the total catches were about 2.8 tonnes and 0.39 tonnes, respectively. The average value of the abundance index of rays resources in kilograms per hour trawling are compared for those areas (Table 1). It is found that the abundance index in the Southern Java was nearly six times higher than that in the Western Sumatera. In addition, the maximum catch per hour in the southern Java was almost 5 times (4.8) higher compared with that in the western Sumatera. Based on the standard deviation of the average, it is found that the variation of the of abundance index in the western Sumatera was almost twice higher than in the southern Java. This indicates that the ray resources in the southern Java during the survey period were found more frequenty and abundance than those found in the western Sumatera.

\begin{tabular}{|c|c|c|}
\hline ltems & Southern Java & Western Sumatera \\
\hline No. Trawl station & $\begin{array}{c}48 \\
2,840.7\end{array}$ & 19 \\
\hline \multirow[t]{2}{*}{ Total catch (kgs) } & $\begin{array}{c}2,840.7 \\
\text { Index of stock abundance (kgs per hours) }\end{array}$ & $3,86.3$ \\
\hline & $\begin{array}{c}\text { Index of stock abundance (kgs per hours) } \\
318.0\end{array}$ & \\
\hline Maximum & 318.0 & 66.0 \\
\hline Minimum & 0.1 & 0.3 \\
\hline Mean & 115.9 & 19.3 \\
\hline Standard Deviation & 82.2 & 23.2 \\
\hline \multirow{2}{*}{ Coefficient of Variation (\%) } & 0.7 & 1.2 \\
\hline & $95 \%$ Confidence limits (Mean $\pm\left(t_{n-1}\right)^{*}(s / \sqrt{ } n)$ & \\
\hline Upper Limit & 139.75 & 30.48 \\
\hline Lower Limit & 92.05 & 8.12 \\
\hline & Calculation of stock density & \\
\hline $\begin{array}{l}\text { Area swept by the gear }\left(\mathrm{km}^{2}\right) \\
\text { Escapement factor }\end{array}$ & 0.0588 & 0.0588 \\
\hline $\begin{array}{l}\text { Escapement factor } \\
\text { Stock Density (tones } \mathrm{km}^{-2} \text { ) }\end{array}$ & $\begin{array}{l}0.5 \\
3.94\end{array}$ & $\begin{array}{l}0.5 \\
0.66\end{array}$ \\
\hline
\end{tabular}

\section{Table 1. Stock abundance index and stock density of rays resources in the Indian Ocean}

Based on the stock abundance index data, the estimated stock density in the southern Java is approximately 3.94 tonnes $\mathrm{km}^{-2}$, this value is about six time higher than that calculated for the western Sumatera (Table 1). Potential estimation (standing stock size) is obtained by multiplying the stock density and the area of the sea surface (survey area). With some certain assumptions and estimations of other parameters discribed in the Gulland's formula (1993), the potential yield of ray resources in the Indian Ocean can be calculated.
These calculated figures are only based on one period of survey. As already known that seasonal phenomena would always attached to any fisheries everywhere in the world ocean. So, it is likely that seasonal variation in the index of abundance and consequently the stock density will also apply to the rays fisheries in the Indian Ocean. In relation to the seasonal fish migration behavior, it is possible that the fish stock abundance in certain waters changing accordingly. 


\section{Stock Abundance Index of Sharks}

Catch rates provide one of the indices of abundance of fish resources. Any external and internal factors influencing fish community and the exploited fish resources in the long term will usually be reflected in the form of catch rate fluctuation. As only one period of survey, catch rate data analyzed will be assumed as a reflection from the actual fish abundance during the period of survey. From a total of 41 successful trawl fishing stations carried in the southern Java and 28 stations in the western Sumatera, it indicates that the total catch of shark in the southern Java was almost $50 \%$ higher than in the western Sumatera (Table 2). The maximum catch rate in the western Sumatera was more than three time higher compared with the maximum catch rate in southern Java, however the difference of both the minimum and the mean catch rate in these areas was not statistically significant.

Looking at the coefficient of variation it is likely that the catch data in term of weight in both areas are not normally distributed as the coefficient of variation value reaching to more than $100 \%$. In other words the distribution of sharks in the Indian Ocean was not evenly distributed. This is not surprising phenomenon as most of shark behavior known as predator.

From the confidence limits, it is likely that the probability of shark caught in substantial number in the southern Java was higher than that in the waters of western Sumatera.

\section{Species Composition of Rays}

During the period of survey, a total of 13 species of rays belonging to the 4 family collected from the catch in the waters of the southern Java and western Sumatera were identified and recorded (Table 3). The detail are 12 species found in the southern Java and only 7 species in the western Sumatera.

The most abundance families in both waters were dominated by the Plesiobatidae and Hexatrygonidae. More than $80 \%$ of the rays catches found in the southern Java, consisted of Plesiobatis sp. and Plesiobatis daviesi of the family Plesiobatidae, while in western Sumatera the same species contributed to more than $60 \%$. The second most abundance family after the Plesiobatidae was the Hexatrygonidae that consisted of only one species, the Hexatrygon longirostra with the contribution for the southern Java and western Sumatera were about 11 and $33 \%$ of each of the total catch respectively (Tables 3 ).

Other relatively abundance species in the southern Java was Bathyraja sp.1 that contributed about $5 \%$ to the total catch, while in the western Sumatera the similar position was placed by the species Torpedo tokionis that contributed about $3.2 \%$.

\section{Species Composition of Sharks}

During the survey period there were 21 species identified belonging to the 11 families, it is likely that the families of Mitsukurinidae, Hexanclidae and Somniosidae were only caught in the waters of western Sumatera,while Triakidae and Carcharhinidae were only caught in the southern Java.

The most dominant sharks family in the southern Java was Centroporidae while in the western Sumatera was Mitsukurinidae. The family Centroporidae seem to be commonly found in both southern Java and western Sumatera, with the species Centrophorus moluccensis, Centrophorus sp. 1 and Centrophorus sp.2, provide the most dominant shark found in the catch (Table 4). .

Table 2. Catch rate $(\mathrm{c} / \mathrm{h})$ of mesopelagic sharks in the Indian Ocean

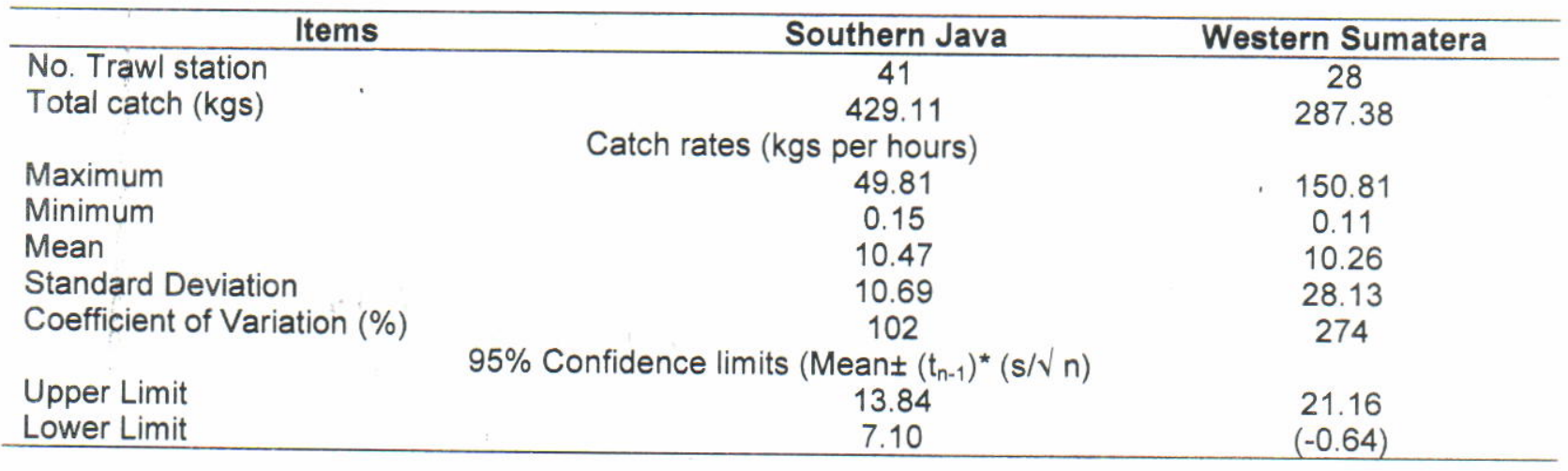


Table 3. Species composition of deep sea rays in the Indian Ocean (May to June 2005)

\begin{tabular}{|c|c|c|c|c|c|c|c|}
\hline \multirow{2}{*}{\multicolumn{2}{|c|}{ Family }} & \multirow{2}{*}{\multicolumn{2}{|c|}{ Species }} & \multicolumn{2}{|c|}{$\begin{array}{c}\text { Southern } \\
\text { Java }\end{array}$} & \multicolumn{2}{|c|}{$\begin{array}{l}\text { Western } \\
\text { Sumatera }\end{array}$} \\
\hline & & & & kg & $\%$ & $\mathrm{~kg}$ & $\%$ \\
\hline 1. & Torpedinidae & 1 & Torpedo tokionis & 7.18 & 0.25 & 11.80 & 3.21 \\
\hline \multirow[t]{9}{*}{2} & Rajidae & 2 & Anacanthobatis borneensis & 1.92 & 0.07 & - & - \\
\hline & & 3 & Acanthobatis sp. & 0.35 & 0.01 & - & - \\
\hline & & 4 & Bathyraja sp. 1 & 144.59 & 5.09 & - & - \\
\hline & & 5 & Bathyraja sp.2 & 18.16 & 0.64 & - & - \\
\hline & & 6 & Bathyraja sp.3 & 1.17 & 0.04 & - & - \\
\hline & & 7 & Dipturus sp. & 5.07 & 0.18 & 6.25 & 1.70 \\
\hline & & 8 & Okamejei sp. & 21.8 & 0.77 & - & - \\
\hline & & 9 & Raja sp. & - & - & 3.01 & 0.82 \\
\hline & & 10 & Rajidae sp. & 29.13 & 1.03 & 2.85 & 0.78 \\
\hline \multirow[t]{2}{*}{3} & Plesiobatididae & 11 & Plesiobatis daviesi & 679.83 & 23.93 & 29.00 & 7.90 \\
\hline & & 12 & Plesiobatis sp. & $1,624.88$ & 57.20 & 192.06 & 52.33 \\
\hline 4 & Hexatrygonidae & 13 & Hexatrygon longirostra & 306.69 & 10.80 & 122.06 & 33.26 \\
\hline \multicolumn{4}{|c|}{ Total } & $2,840.75$ & 100 & 367.03 & 100 \\
\hline
\end{tabular}

Table 4. Species composition of mesopelagic sharks in the Indian Ocean

\begin{tabular}{|c|c|c|c|c|c|c|c|}
\hline \multirow{2}{*}{\multicolumn{2}{|c|}{ Family }} & \multirow{2}{*}{\multicolumn{2}{|c|}{ Species }} & \multicolumn{2}{|c|}{ Southern Java } & \multicolumn{2}{|c|}{ Western Sumatera } \\
\hline & & & & (kg) & (\%) & (kg) & $(\%)$ \\
\hline 1 & Mitsukurinidae & 1 & Mitsukurina owstoni & - & - & 150.00 & 52.2 \\
\hline 2 & Alopiidae & 2 & Alopias pelagicus & 20.90 & 4.9 & - & - \\
\hline \multirow[t]{4}{*}{3} & Scyliorhinidae & 3 & Apristurus sp. 1 & 9.68 & 2.3 & 5.68 & 2.0 \\
\hline & & 4 & Apristurus sp. 2 & 1.78 & 0.4 & - & - \\
\hline & & 5 & Scyliorhinus sp. & - & - & 0.14 & 0.0 \\
\hline & & 6 & Scyliorhinidae sp. & 0.84 & 0.2 & - & - \\
\hline \multirow[t]{2}{*}{4} & Triakidae & 7 & Hypogaleus hyugaensis & 0.64 & 0.1 & - & - \\
\hline & & 8 & Hemitriakis sp. & 0.72 & 0.2 & - & - \\
\hline 5 & Carcharhinidae & 9 & Carcharhinidae sp. & 9.50 & 2.2 & - & - \\
\hline 6 & Hexanclidae & 10 & Heptranchias perlo & - & - & 1.03 & 0.4 \\
\hline 7 & Etmopteridae & 11 & Etmopterus sp. & 0.07 & 0.0 & 0.44 & 0.2 \\
\hline 8 & Somniosidae & 12 & Zameus squamulosus & - & - & 2.32 & 0.8 \\
\hline \multirow[t]{5}{*}{9} & Centrophoridae & 13 & Centrophorus moluccensis & 126.67 & 29.5 & 42.86 & 14.9 \\
\hline & & 14 & Centrophorus sp. 1 & 128.90 & 30.0 & 19.96 & 6.9 \\
\hline & & 15 & Centrophorus sp.2 & - & - & 52.78 & 18.4 \\
\hline & & 16 & Deania calcea & 1.42 & 0.3 & - & - \\
\hline & & 17 & Deania histricosa & 1.11 & 0.3 & - & - \\
\hline \multirow[t]{3}{*}{10} & Squalidae & 18 & Squalus brevirostris & 12.47 & 2.9 & - & - \\
\hline & & 19 & Squalus sp.1 & 45.12 & 10.5 & 3.54 & 1.2 \\
\hline & & 20 & Squalus sp. 2 & 0.58 & 0.1 & 0.14 & 0.05 \\
\hline 11 & Squatinidae & 21 & Squatina tergocellatoides & 68.74 & 16.0 & 8.50 & 3.0 \\
\hline \multicolumn{4}{|c|}{ Total } & 429.11 & 100 & 287.38 & 100 \\
\hline
\end{tabular}

Compared with the total number of 43 species reported by Widodo \& Widodo (2002), the total number of species of only 21 found during the survey was relatively smaller. The two species that caught during the survey and the previous period were Alopias pelagicus and Centrophorus moluccensis. With these records it is likely that the number of sharks species found in southern Java was more than 57 species. It could also be concluded that the sharks resources in the waters of southern Java were more diverse compared with the same resources in the, waters of western Sumatera. These are also seen in the percentage catch composition where $98 \%$ of the catch consisted of 8 species ranging from approximately $10 \mathrm{kgs}$ to $129 \mathrm{kgs}$ for each species. These species were Centrophorus moluccensis, Centrophorus sp.1, Squatina tergocellatoides, Squalus sp. 1 , Squalus brevirostris, Carcharhinus sp., Apristurus $\mathrm{sp}$. 1, and Alopias pelagicus. In the waters of 
western Sumatera, $92 \%$ of the catch consisted of only four species, these were Mitsukurina owstoni, Centrophorus sp.2, Centrophorus moluccensis, and Centrophorus sp. 1.

The species Alopias pelagicus and Centrophorus moluccensis are widely distributed in the Indian Ocean. According to Compagno (1984), $A$. pelagicus that mostly live in shallow waters pelagic zone, sometime it can also be found in mesopelagic waters. This species was reported to be caught in the depth of $152 \mathrm{~m}$, while during this survey the species was caught at depth of $710 \mathrm{~m}$ in the southern Java. The species C. moluccensis, may provide the demersal sharks inhabiting the bottom floor at the depth range of 128 to $823 \mathrm{~m}$ (Compagno, 1984), while during the survey this species was caught in the deeper waters at the depth range of 284 to $1245 \mathrm{~m}$.

In the waters of western Sumatera, sharks contributed to the total catch of about $11,6 \%$. From a total of 12 species found in this area, the species Mitsukirina owstoni (family Mitsukurinidae) was caught only one specimen with the total weight of $>150 \mathrm{kgs}$, followed by other dominated species Centrophorus sp.2 and Centrophorus moluccensis (family Centrophoridae).

\section{Distribution of Rays}

Information on the spatial distribution provide, one of the basic aspects needed for the exploitation and development of fish resources. Based on the results of the trawling operations, a wide range of catch rates noted. It ranges in southern Java from
0.1 to $318 \mathrm{kgs}$ and from 0.3 to $66 \mathrm{kgs}$ of rays for the western Sumatera.

Horizontal distribution of deep sea rays in the southern Java and western Sumatera is illustrated in Figure 1 and 2, respectively. From the first figure it is shown that the catch of rays was widely distributed along the southern Java coast from West Java to East Java with the most abundance of rays found in the southern part of Yogyakarta.

In Figure 2, it is shown that the most abundance of rays resources is found in the waters around Enggano, and decreased toward the northern part of the survey area.

For the vertical distribution point of view, catch rate data analyzed were grouped into three depth strata $<500 \mathrm{~m}, 500$ to $750 \mathrm{~m}$, and 750 to $1,000 \mathrm{~m}$. The depth distribution of rays catches is presented in the Figure 3. In the waters of southern Java, higher catch rate of rays resources is found in the depth strata of $<500 \mathrm{~m}$. The similar case is also happened for the ray resources distribution in the waters of western Sumatera in a lower scale.

\section{Distribution of Sharks}

In the waters of southern Java the range was between $<1 \mathrm{~kg}$ to approximately $50 \mathrm{kgs}$, wile in western Sumatera was between $<1 \mathrm{~kg}$ to $150 \mathrm{kgs}$. The plots of the catch in each fishing station were geographically depicted in the Figure 4. In southern Java, the sharks were likely concentrated around the territorial water from south of Cilacap until south of Yogyakarta and proceed eastwards to the southern part of Pacitan, East Java. In the western

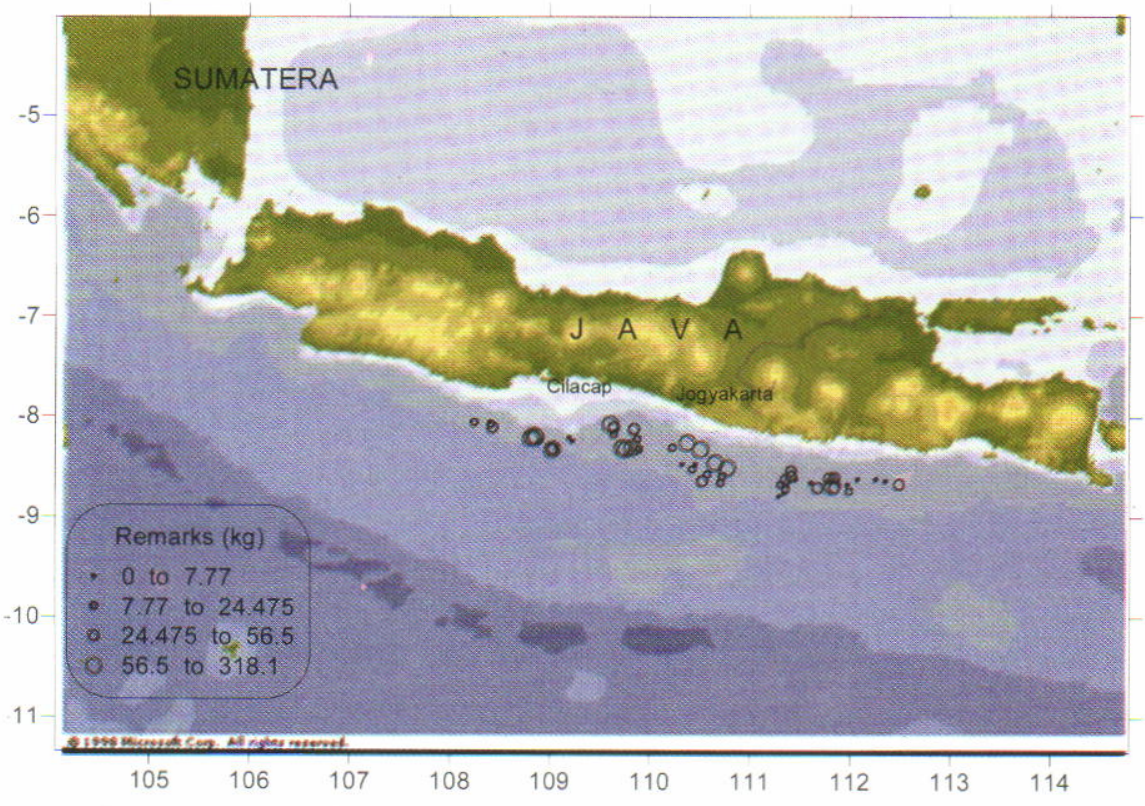

Figure 1. Horizontal distribution of deep sea rays in the waters of the Southern Java. 


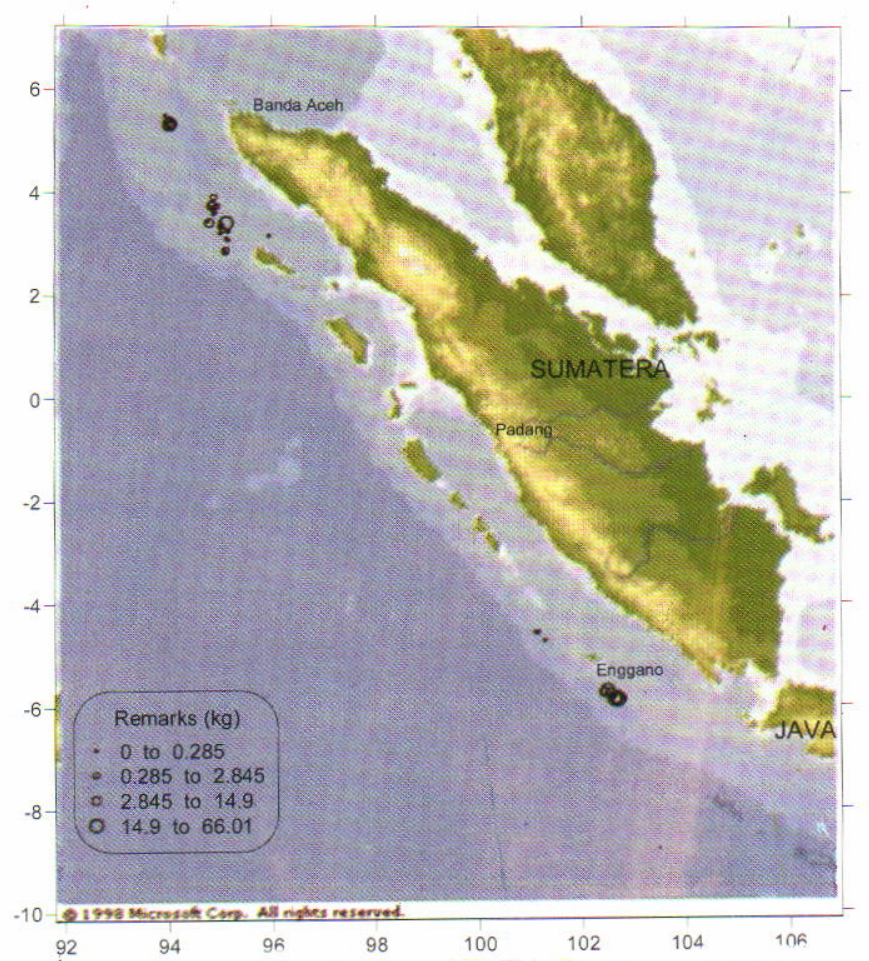

Figure 2. Horizontal distribution of deep sea rays in the waters of the Western Sumatera.

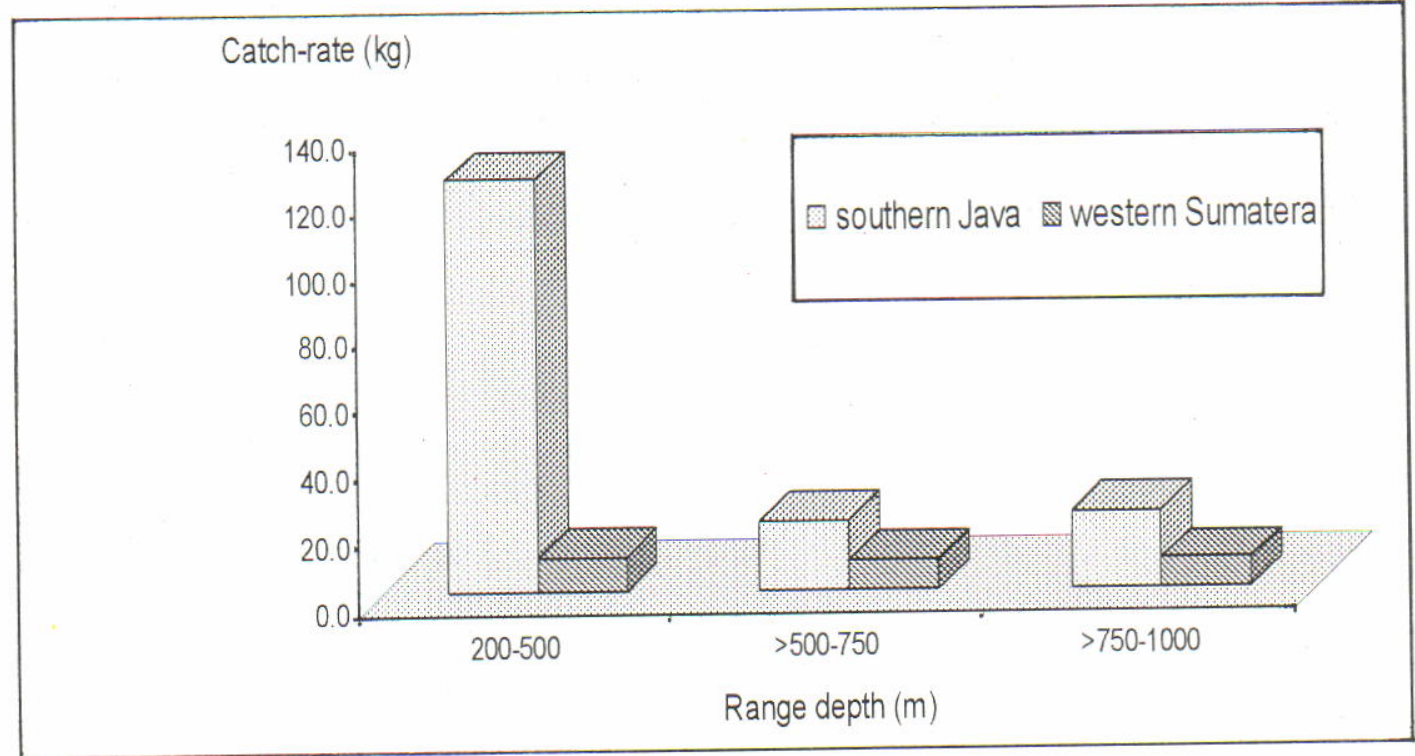

Figure 3 .

Average catch rate of deep sea rays in the three depth strata in the Indian Ocean (May to June 2005).

Sumatera high catches of shark were found around Enggano island and around the northwest of Simeulu island.

The vertical distribution of the mesopelagic sharks in the Indian Ocean was grouped into three depth strata, the $<500 \mathrm{~m}, 500$ to $750 \mathrm{~m}$ and 750 to $1,000 \mathrm{~m}$ (Figure 5). The histogram in each depth strata depicting the amount of catch rate. Based on this figure it is likely that the mesopelagic sharks during the survey period in both southern Java and

western Sumatera seem to be concentrated in the depth strata of 500 to $750 \mathrm{~m}$. It is also implied that the lowest concentration of sharks in the waters of southern Java was occurred in the depth strata of < $500 \mathrm{~m}$, while in the western Sumatera was in the 750 to $1,000 \mathrm{~m}$ depth strata. . 


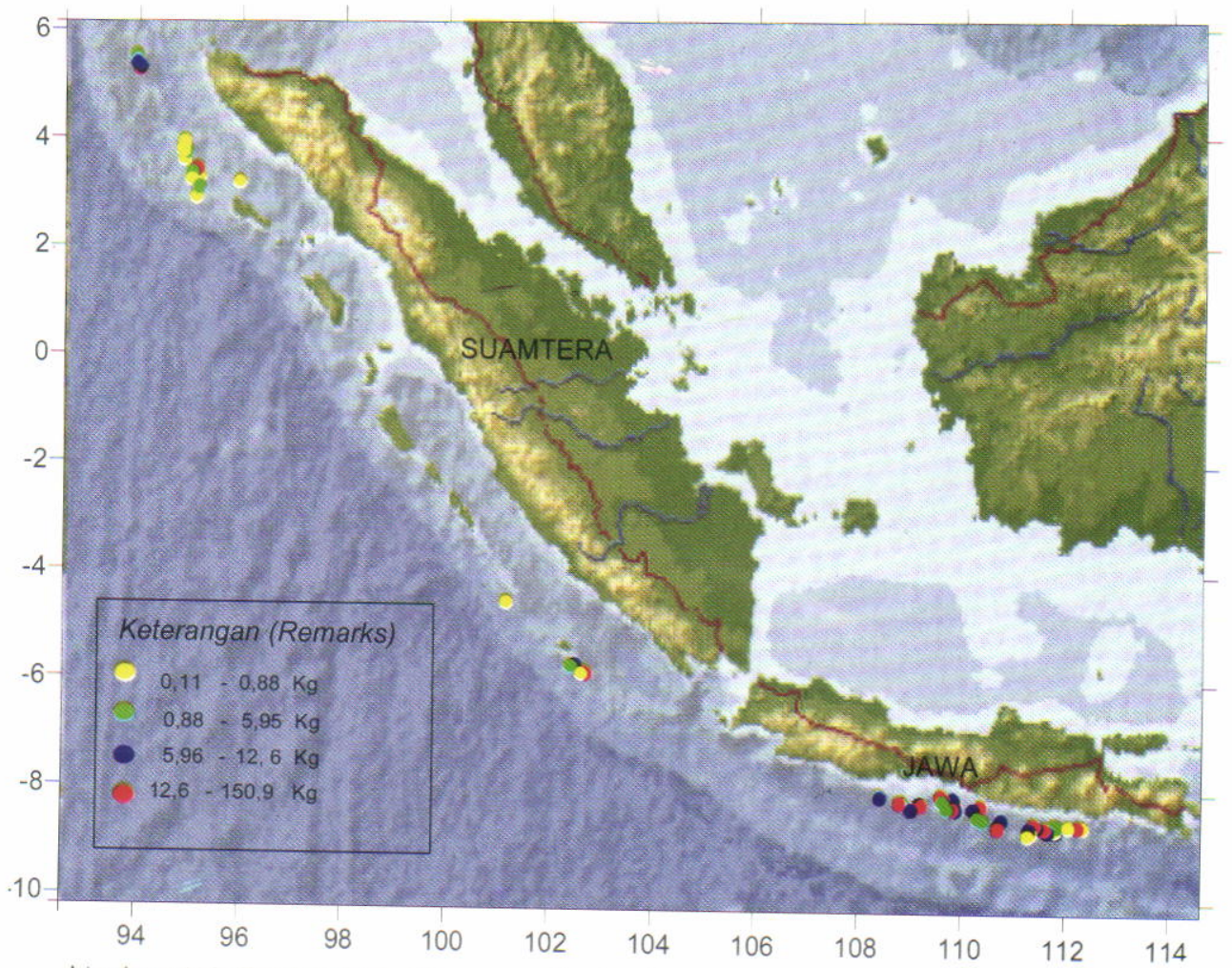

Figure 4. Horizontal distribution of mesopelagic sharks in the waters of southern Java and western Sumatera.

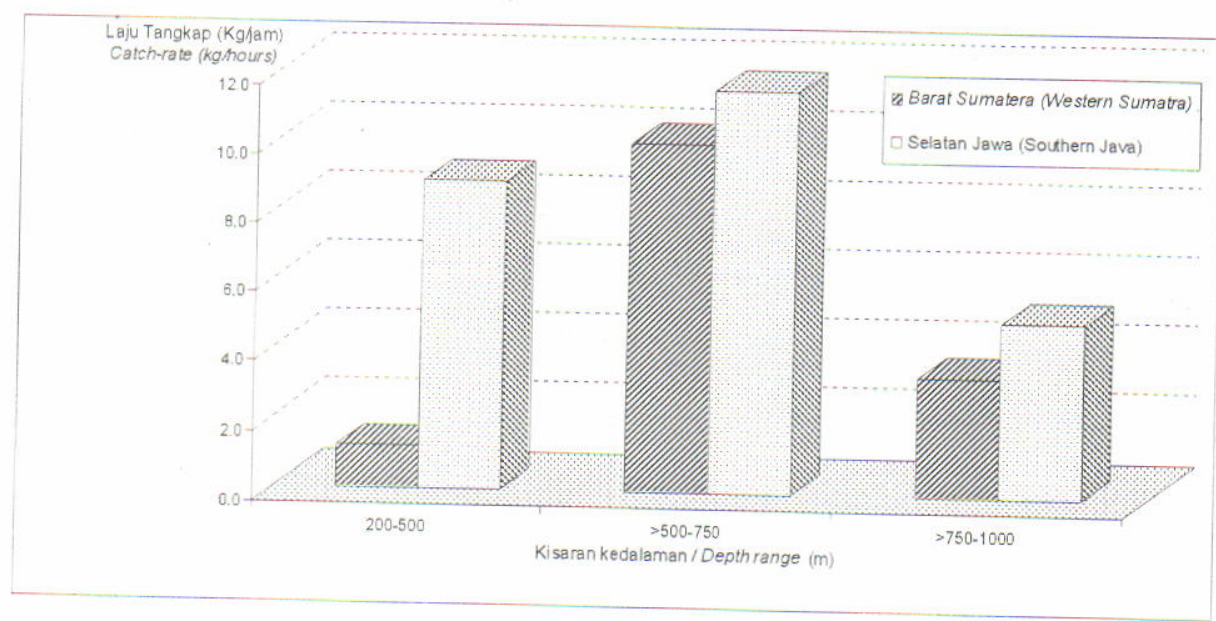

Figure 5.

Histogram of average catch rate of mesopelagic sharks in the Indian Ocean.

\section{CONCLUSION}

The average catch rates as an index of abundance of ray resource in the Southern Java was about six timer higher than in the Western Sumatera. The probability of success of fishing on rays resources in the southern Java was between 92 to $140 \mathrm{kgs}$ per trawl hour, while in the western Sumatera would only between 8 to $30 \mathrm{kgs}$ per trawl hour. Standing stock size is obtained by multiply the stock density and the survey area. Potential estimation is obtained by multiplying the stock density and the area of the sea surface (survey area) that is called the standing stock size. With some certain assumptions and estimations of other parameters the potential yield of rays resources in the Indian Ocean can be calculated. Regarding diversity aspects, a total of 13 species of rays belonging to the 4 family found during the survey period were identified and recorded. The detail 12 
species found in the southern Java and only 7 species in the western Sumatera. It seems that the diversity of rays resources in the waters of southern Java was relatively higher than the same resources in the western Sumatera. The most abundance families in both waters are the Plesiobatidae, with the species Plesiobatis sp., Plesiobatis daviesi, and Hexatrygonidae. The latter is only consisted of one species, Hexatrygon longirostra.

During the survey period, there were 21 species belonging to 11 families of mesopelagic sharks found in the waters of the Indian Ocean. The most dominant species in weight in the southern Java were Centrophorus sp. and Centrophorus moluccensis (family Centrophoridae), while in the western Sumatera was Mitsukurina owstoni. During the period of survey, May to June 2005, the total catch of sharks in the southern Java was almost $50 \%$ higher than in the western Sumatera. The maximum catch rate in the western Sumatera was more than three time higher compared with the maximum catch rate in southern Java, however the difference of the minimum and the mean catch rate in both areas was not statistically significant. Based on catch rate data the density of the sharks resources in the waters of southern Java during the period of survey was about 0.36 tonnes $\mathrm{km}^{-2}$, while in the western Sumatera was 0.35 tonnes $\mathrm{km}^{-2}$. It is likely that the density of mesopelagic sharks in both survey areas was also not significant. Assuming that information on the natural mortality rate (M) and the potential constant (a) are available the estimated potential yield (Py) can also be calculated using the Gulland's formula. From the catch compositions, maybe that during the survey period the family Mitsukurinidae, Hexanclidae and Som̃niosidae were only available and caught in the waters of western Sumatera, while Triakidae and Carcharhinidae were only caught in the southern Java.

\section{REFERENCES}

Anonymous. 2005. Statistik perikanan Indonesia. Direktorat Jenderal Perikanan Tangkap. Departemen Kelautan dan Perikanan.

Allen, G. 1997. Marine Fishes of tropical Australia and South-East Asia: A field guide for anglers and divers, western Auastralian Museum. 292 pp.

Burhanuddiṅ, S. Martosewojo, A. Djamali, \& R. Moeljanto. 1984. Perikanan demersal di Indonesia. Lembaga Oseanologi Nasional. Lembaga IImu Pengetahuan Indonesia. p 9.
Castro, J. I., C. M. Woodley, \& R. L. Brudek. 1999. A preliminary evolution of the status of shark species. National Oceanographic and Atmospheric Administration. National Marine Fisheries Service Southeast Fisheries Science Centre.. Miami. Florida. USA. FAO. Fisheries Technical Paper. No.380.

Chen, C. T., K. M. Liu, \& Y. C. Cheng. 1997. Reproductive biology of the bigeye thresher shark, Alopias superciliosus Lowe, 1839 (Chondrichthyes: Alopiidae), in the Northwestern Pasific. Ichthyol. Res. 44: 227 235.

Compagno, L. J. V. 1984. FAO. Species catalogue. Vol.4. Sharks of the World. An Annotated and Illustrated Catalogue of Shark Species Known to Date. Part 1. Hexanchiformes to Lamniformes: VIII: 1-250 pp. Part 2. Carcharhiniformes: $X . \cdot 251-655$ pp. FAO Fisheries Synopsis. 125: 1-655.

Dharmadi, A. A. Widodo, \& J. Widodo. 2002. Aspek biologi dan penangkapan cucut di Cilacap. Jurnal Penelitian Perikanan Indonesia. Edisi Sumber Daya dan Penangkapan. Vol.8. No.1. p. 57-67.

Dharmadi \& Fahmi. 2003. Fisheries characteristics of artisanal sharks and rays in Indonesian waters. International Seminar on Marine and Fisheries. AMFS. MMAF.Jakarta. Pp: 122-129.

Dharmadi, Fahmi, \& W.White. 2003. Pelagic and bottom shark by catch in the Indonesia tuna long line fishery. International Seminar on Marine and Fisheries. AMFS. MMAF.Jakarta. Pp: 130-135.

Demski, L. S. \& John P. W. 1993. The Reproduction and development of sharks, skates, rays, and ratfishes introduction. History, Overview, and Future Prospects in J. P. Wourms \& L. S. Demski (Eds). The Reproduction and Development of Sharks, Skates, Rays, and Ratfishes. Kluwer Academic Publishers. London. 299 pp.

FAO. 1999. Indicators for sustainable development of marine capture fisheries. FAO Tech. Guidelines for Responsible Fisheries No.8. FAO. Rome. 68 p.

FAO. 2002. Fisheries Management 1. Coservation and management of Shark. FAO Tech. Guidelines for Responsible Fisheries. No.4. Suppl. 1. Rome. 37 p. 
Gulland, J. A. 1983. Fish stock assessment. A manual of basics method. FAOMiley series on food and agriculture. Vol.1. John Wiley \& Sons. $223 \mathrm{p}$.

Gloerfelt-Tarp, T. \& P. J. Kailola. 1984. Trawled fish of the southern Indonesia and northwestern Australia. ADAB-GTZ-DGF Indonesia. 406 pp.

Hufiadi, E. Nurdin, J. Widodo, \& A. Anung. 2003. Aspek penangkapan pari di perairan utara Jawa dengan menggunakan jaring liongbun, pancing senggol, dan cantrang. Prosiding Hasil-Hasil Riset. Pusat Riset Perikanan Tangkap. p 25-30.

Nakabo, T. 2000. Fishes of Japan with pectoral keys to the species. Second edition. Tokai University Press. Tokyo. Book I: 865 pp.

Pralampita W. A. 2003. Length, weight, and sex ratio of the requiem shark of the genus Carcharhinus and Prionace glauca of the
Carcharhinidae landed from the Indian Ocean south of Java, Bali, and Nusa Tenggara. Jurnal Penelitian Perikanan Indonesia. Vol.9. No.3: 35-47.

Shindo, S. 1973. General review of the trawl fishery and the demersal fish stock of the South China Sea. FAO. Fish. Tech. Pap. (120). 49 p.

Sparre, P. \& S. C. Venema. 1992. Introduction to Tropical Fish Stock Assessment. Part 1. Manual FAO. Fish. Tech.Pap. (306/1). Rev. I: $378 \mathrm{p}$.

Saleh, M., R. S. Embun, S. Wijandi, N. Indriati, \& Nurul Haq. 1995. Ekstraksi lem ikan dari tulang ikan pari. Jurnal Penelitian Perikanan Indonesia. Vol.1. No.2. p 28-38.

Widodo, A .A. \& J. Widodo. 2002. Perikanan cucut artisanal di perairan Samudera Hindia Selatan dan Lombok. Jurnal Penelitian Perikanan Indonesia. Edisi Sumber Daya dan Penangkapan. Vol.8. No.1. p 75-83. 